\title{
THE EFFECTS OF ADDING DIFFERENT CARBON ON GROWTH AND SURVIVAL RATE OF TILAPIA FRY (Oreochromis niloticus)
}

\author{
Rodhi Firmansyah* ${ }^{1}$, Arsanti ${ }^{1}$, Nabilah Hanun Panggabean ${ }^{2}$, Muhaimin Umri Nasution ${ }^{2}$ \\ ${ }^{1}$ Dosen Program Studi Akuakultur Sekolah Tinggi Perikanan dan Kelautan Matauli \\ ${ }^{2}$ Mahasiswa Program Studi Akuakultur Sekolah Tinggi Perikanan dan Kelautan Matauli \\ *rodhi.aquaculture@gmail.com
}

\begin{abstract}
The Utilization of appropriate carbon sources will have a good impact on the application of biofloc technology in aquaculture. This study aims to effects of adding different carbon on growth and survival rate of tilapia fry (Oreochromis niloticus). The fries were kept by the densities 30 fries/tank. This study used a completely randomized design (CRD) with 4 treatments and 3 replications. The treatments were the addition of different carbon sources on the media biofloc: A (tapioca), B (molasses), C (wheat flour), and $\mathrm{K}$ (control). The results showed that the absolute rate of weight and length were found on the treatment of molasses (B) was 5.84 grams, $3.5 \mathrm{~cm}$ and significantly different from the other treatments $(\mathrm{P}<0.05)$. While the highest survival rate is $83.33 \%$ at molasses (B). The mean temperature at 28.1 to $30.00{ }^{\circ} \mathrm{C}$, the DO from 5.00 to $7.60 \mathrm{mg} / \mathrm{L}$ and $\mathrm{pH} 5.00-7.20$.
\end{abstract}

Keywords: Tilapia, Molasses, Growth, Survival Rate

\section{PENDAHULUAN}

Sektor perikanan budidaya merupakan salah satu sektor yang memberikan kontribusi untuk ketahanan pangan terutama dari penyedian sumber protein hewani, selain itu perikanan budidaya juga dapat menyediakan lapangan pekerjaan sehingga berdampak terhadap peningkatan pendapatan. Ikan nila adalah spesies budidaya penting Indonesia, salah satu ikan konsumsi dari 10 jenis ikan yang menjadi target peningkatan produksi yang dicanangkan Kementerian Kelautan dan Perikanan (KKP) pada tahun 2014, menurut KKP (2016) terjadi peningkatan total produksi budidaya ikan nila selama kurun waktu 2015 - 2018 yaitu sebesar 12,85\%. Tingginya total produksi tersebut mendorong dilakukannya usaha yang dapat meningkatkan produktivitas ikan nila. Peningkatan produksi ikan nila masih memiliki kendala yang saat ini masih belum teratasi salah satunya adalah rendahnya kualitas dan kuantitas benih (Rivandi, 2014). Ketersedian benih merupakan salah satu faktor penentu keberhasilan suatu proses budidaya ikan. Salah satu bentuk upaya untuk meningkatkan kualitas dan kuantitas benih adalah penerapan teknologi bioflok (Sulistiani 2015) dalam proses pendederannya.

Sektor perikanan budidaya merupakan salah satu sektor yang memberikan kontribusi untuk ketahanan pangan terutama dari penyedian sumber protein hewani, selain itu perikanan budidaya juga dapat menyediakan lapangan pekerjaan sehingga berdampak terhadap peningkatan pendapatan. Ikan nila adalah spesies budidaya penting Indonesia, salah satu ikan konsumsi dari 10 jenis ikan yang menjadi target peningkatan produksi yang dicanangkan Kementerian Kelautan dan 
Perikanan (KKP) pada tahun 2014, menurut data KKP (2016) terjadi peningkatan total produksi budidaya ikan nila selama kurun waktu 2015 - 2018 yaitu sebesar $12,85 \%$. Tingginya total produksi tersebut mendorong dilakukannya usaha yang dapat meningkatkan produktivitas ikan nila. Peningkatan produksi ikan nila masih memiliki kendala yang saat ini masih belum teratasi salah satunya adalah rendahnya kualitas dan kuantitas benih (Rivandi, 2014). Ketersedian benih merupakan salah satu faktor penentu keberhasilan suatu proses budidaya ikan. Salah satu bentuk upaya untuk meningkatkan kualitas dan kuantitas benih adalah penerapan teknologi bioflok (Sulistiani 2015) dalam proses pendederannya.

Teknologi bioflok (BFT) adalah salah satu teknologi yang saat ini dikembangkan dalam akuakultur (Hakim, 2017), bioflok merupakan activated sludge (lumpur aktif) yang berasal dari proses pengolahan biologis air limbah (biological wastewater treatment), yaitu pemanfaatan bakteri pembentuk flok (flocs forming bacteria) untuk pengolahan limbah dengan meningkatkan C/N. Salah satu bakteri yang dapat membentuk bioflok adalah Bacillus (Maharani, 2014). Menurut De Schryver dan Verstraete (2009) prinsip BFT yaitu asimilasi nitrogen anorganik yang dilakukan oleh komunitas mikroba heterotrof didalam media budidaya. Biomasa mikroba yeng telah terbentuk selanjutnya dapat dimanfaatkan oleh organisme budidaya sebagai sumber pakan. Sehingga akumulasi limbah nitrogen dapat diminimalisir dan pemanfaatan nutrien dalam pakan dapat ditingkatkan. Manser (2006) menemukan bahwa mikroorganisme dalam bioflok ukurannya 500 mikron hingga $2 \mathrm{~mm}$ sehingga ukuran ini cukup besar untuk dapat dimanfaatkan oleh ikan maupun udang. Konversi nitrogen anorganik menjadi bakteri heterotrof dapat dikontrol dengan penambahan karbon organic, penembahan ini disesuaikan dengan rasio karbon per nitrogen $(\mathrm{C} / \mathrm{N})$ tertentu. Rasio $\mathrm{C} / \mathrm{N}$ dalam pakan yang diajurkan dalam sistem bioflok berkisar antara 10 sampai 20 (Asaduzzaman et al. 2008; Avnimelech 2012; Ballester et al. 2010; Hargreaves 2006).

Penerapan BFT dapat dibentuk dengan sumber karbohidrat organik yang berbeda-beda (Purnomo, 2012), beberapa faktor yang mempengaruhi pembentukan struktur dan formasi flok tersebut adalah sumber karbohidrat organik, sumber karbohidrat yang dipakai umumnya berasal dari hasil limbah produksi pertanian yang bernilai rendah (low-value product) (Crab et al. 2012). Beberapa sumber karbon yang bisa dimanfaatkan antara lain tepung tapioka, molase (Septiani et al., 2014 dan Hari et al., 2004) dan gandum (Aji et al 2014), tepung kanji (Avnimelech, 2007 dan Crab et al, 2012) dan tepung singkong (Avnimelech, 1999). Ada beberapa hal yang menjadi pertimbangan untuk menentukan sumber karbohirat yaitu harga, ketersediaan, biodegradabilitas, dan efisiensi asimilasi bakteri (Emerenciano et al. 2011). Oleh sebab itu pemilihan sumber karbohirat yang tepat sangat mempengaruhi efisiensi dalam menerapkan BFT pada sistem budidaya sehingga pada akhirnya akan berpengaruh terhadap produktifitas budidaya.

Pemanfaatan sumber karbon yang tepat diharapkan dapat memberikan dampak terhadap yang baik dalam penerapan BFT pada pendederan benih ikan nila. Berdasarkan permasalahan tersebut, maka penelitian ini bertujuan untuk mengetahui pengaruh penambahan sumber karbon berbeda pada teknologi bioflok terhadap pertumbuhan dan kelangsungan hidup benih ikan nila (Oreochromis niloticus) yang berbasis sumber daya lokal yang akan memberikan nilai tambah baik dari sisi usaha maupun biaya produksi pakan yang lebih efisien 


\section{METODE PENELITIAN}

Penelitian dilakukan pada bulan Oktober 2018-Juni 2019 di Laboratorium Reproduksi dan Pembenihan Program Studi Akuakultur Sekolah Tinggi Perikanan Kelautan (STPK) MATAULI Pandan, Tapanuli Tengah, Sumatera Utara. Ikan yang diuji digunakan pada penelitian ini adalah benih ikan nila. Jumlah benih yang disiapkan untuk setiap unit perlakuan sebanyak 30 ekor. Bahan yang digunakan sebagai sumber karbon yaitu molase, tepung tapioka, tepung terigu dan EM4 sebagai sumber Probiotik.

Rancangan penelitian ini adalah rancangan acak lengkap (RAL), yang terdiri atas empat perlakuan dengan tiga kali ulangan. Perlakuan yang diuji pada penelitian ini adalah sumber karbon yang berbeda yaitu Tepung Tapioka, Molase dan Tepung Terigu, dengan satu perlakuan kontrol (K)

Benih ikan nila dipelihara selama 30 hari, frekuensi pemberian pakan dilakukan tiga kali sehari, Pakan diberikan sebanyak $5 \%$ dari biomassa total. Untuk menjaga keseimbangan nitrogen dan karbon dilakukan penebaran sumber karbon, yaitu tepung tapioca, terigu dan molase dengan rasio $\mathrm{C} / \mathrm{N}$ yaitu 15 . Pengamatan biomassa dan panjang ikan dilakukan pada hari pertama, 14 dan pada akhir penelitian (hari ke-30).

Data yang diperoleh dianalisis menggunakan uji ANOVA dengan selang kepercayaan 95\%, kemudian di Uji lanjut menggunakan Uji Tukey dengan selang kepercayaan $95 \%$

\section{HASIL DAN PEMBAHASAN Pertambahan Berat Mutlak}

Berdasarkan data pertambahan berat mutlak pasca perlakuan sumber karbon yang berbeda (Gambar 1), hasil penelitian ini menunjukkan bahwa pertambahan berat mutlak pada semua perlakuan bervariasi dengan kisaran $3.70-4.61$ gram pada pemeliharaan 14 hari dan 3.77 - 5.84 gram saat akhir penelitian (30 hari). Dibandingkan dengan kontrol dan perlakuan lainnya, pertambahan berat mutlak benih ikan nila pada penambahan molase (B) menunjukkan hasil yang paling tinggi dari perlakuan lainya.

Hasil uji statistik menunjukkan bahwa pertambahan berat mutlak pada penambahan molase (B) berbeda nyata dari semua perlakuan $(\mathrm{P}<0,05)$, dan pada akhir penelitian perlakuan penambahan tapiokan (A) dan terigu (B) berbeda nyata dari perlakuan kontrol $(\mathrm{P}>0,05)$.

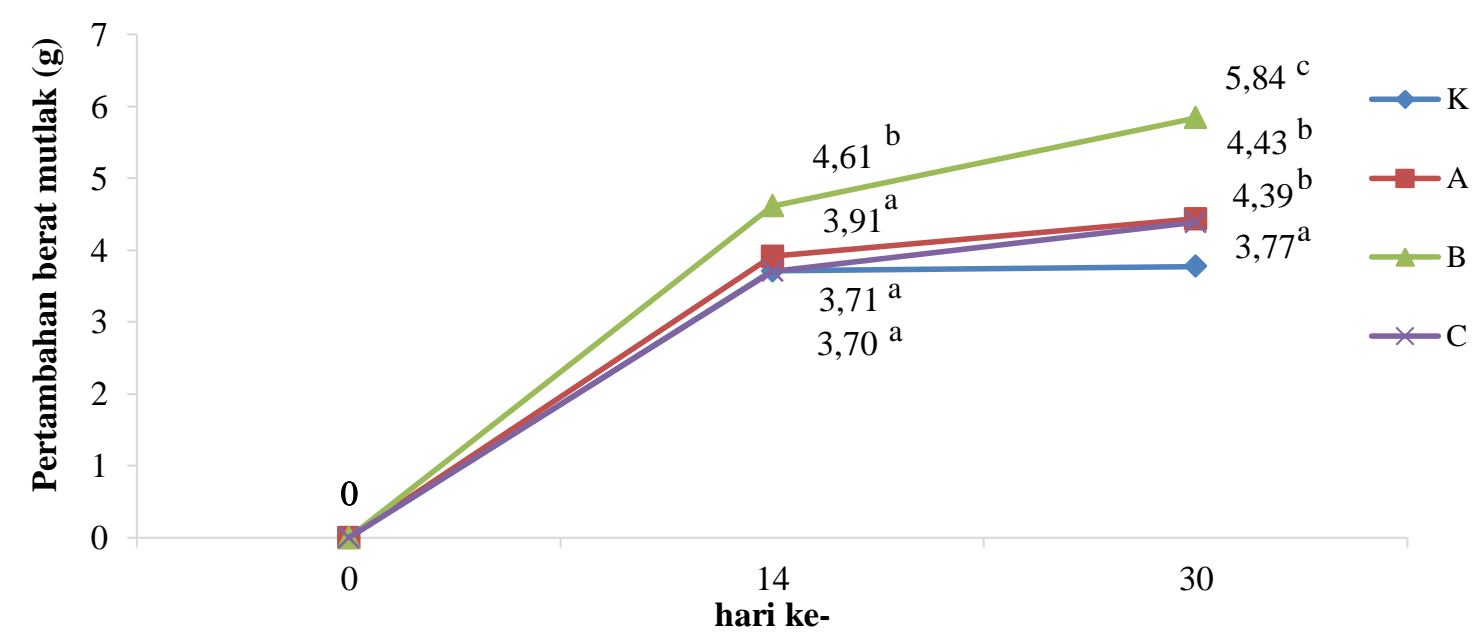

Gambar 1. Pertambahan berat mutlak benih ikan nila pemeliharaan 0,14 dan 30 hari. $K=$ Kontrol, $A$ $=$ Tapioka, $\mathrm{B}=$ Molase, $\mathrm{C}=$ Terigu. Huruf yang berbeda di nilai grafik menunjukkan perbedaan nyata $(\mathrm{P}<0,05)$. 
Pemberian sumber karbon berbeda pada pendederan benih ikan nila dengan teknologi bioflok memberikan pertambahan berat lebih baik dibandingkan tanpa penambahan suber karbon (kontrol). Azim dan Little (2008) menyatakan bahwa aplikasi BFT meningkatkan pertambahan bobot dan produksi bersih nila (O. niloticus). Pertambahan berat mutlak pada perlakuan A, B dan $\mathrm{C}$ berbeda nyata $(\mathrm{P}<0,05)$ dibandingkan perlakuan kontrol $(\mathrm{K})$, ini disebabkan karena biomassa bioflok mampu dimanfaatkan oleh ikan nila sebagai sumber pakan tambahan. Kadungan protein yang terdapat pada biomasa bioflok ini cukup tinggi sehingga dapat mempercepat pertumbuhan. Menurut Azim dan Little (2008), Ikan nila merupakan ikan yang dapat memakan partikel, termasuk bakteri yang tersuspensi. Selain itu ikan nila juga merupakan ikan yang memiliki kemampuan sebagai filter feeder dan tergolong ikan omnivora, sehingga dapat memanfaatkan kelimpahan bioflok untuk pakan alami bernutrisi sehingga dapat memacu pertumbuhan ikan lebih cepat. Menurut De Schryver et al. (2008) aplikasi BFT berperan penting untuk meningkatkan efisiensi pemanfaatan pakan oleh ikan, ini juga didukung oleh penelitian Avnimelech (1999) yang menemukan bahwa nila dapat memakan suspensi dari hasil pembentukan mikrobial flok yang ada didalam media budidaya. Sementara hal sebaliknya tidak terjadi pada perlakuan kontrol.

Tingkat pertambahan berat mutlak perlakuan B berbedanyata dari perlakuan A dan $\mathrm{C}$, ini diduga pada perlakua $\mathrm{B}$ mempunyai populasi fitoplankton dan bakteri nitrifikasi yang cukup besar, karena menurut Ebeling et al. (2006) dalam Rohmana (2009), menemukan bahwa fitoplankton dan bakteri nitrifikasi akan memanfaatkan alkanilitas sebagai sumber karbon anorganik. Hal ini juga diduga karena bakteri heterotrof lebih cepat dan mudah mengasimilasi molase menjadi biomassa sel karena molase tersusun atas karbohidrat sederhana. Sedangkan pada perlakuan A dan C, bakteri heterotrop membutuhkan waktu lebih lama untuk mengasimilasinya sebab sumber karbon perlakuan $\mathrm{A}$ dan $\mathrm{C}$ terusun atas karbohidrat komplek (Purnomo, 2012). Hargreaves (1998) menambahkan bahwa bakteri memegang peranan yang penting untuk dekomposisi nutrien organik di dalam kegiatan produksi akuakultur maupun di sedimen tambak. Purnomo (2012) menambahkan bahwa penambahan sumber karbohidrat organik kedalam media budidaya dapat meningkatkan produksi budidaya nila sebesar $43-49 \%$ dibandingkan budidaya tanpa penambahan karbohidrat.

\section{Pertambahan Panjang Mutlak}

Pengaruh penambahan sumber karbon yang berbeda terhadap pertambahan panjang mutlak benih ikan nila menunjukkan hasil yang berbeda nyata $(\mathrm{P}<0,05)$ (Gambar 2). Pada pemeliharaan hari ke-14, Pertambahan panjang mutlak pada perlakuan molase (B) memiliki nilai tertinggi yaitu $1.67 \mathrm{~cm}$ dan berbeda nyata dari perlakuan lainnya $(\mathrm{P}<0,05)$. Nilai pertambahan panjang mutlak terendah pada pelakuan kontrol $(\mathrm{K})$ sebesar $0.94 \mathrm{~cm}$, sedangakan perlakuan tapiokan (A) dan terigu (C) tidak berbedanyata dengan perlakuan control (K) $(\mathrm{P}>0,05)$. Pertambahan panjang mutlak setelah benih ikan nila dipelihara selama 30 hari tertinggi pada perlakuan molase (B) sebesar $3.52 \mathrm{~cm}$ dan terendah pada perlakuan control (K) yaitu $3.02 \mathrm{~cm}$. Perlakuan molase (B) berbeda nyata dari perlakuan lainya $(\mathrm{P}<0,05)$. 


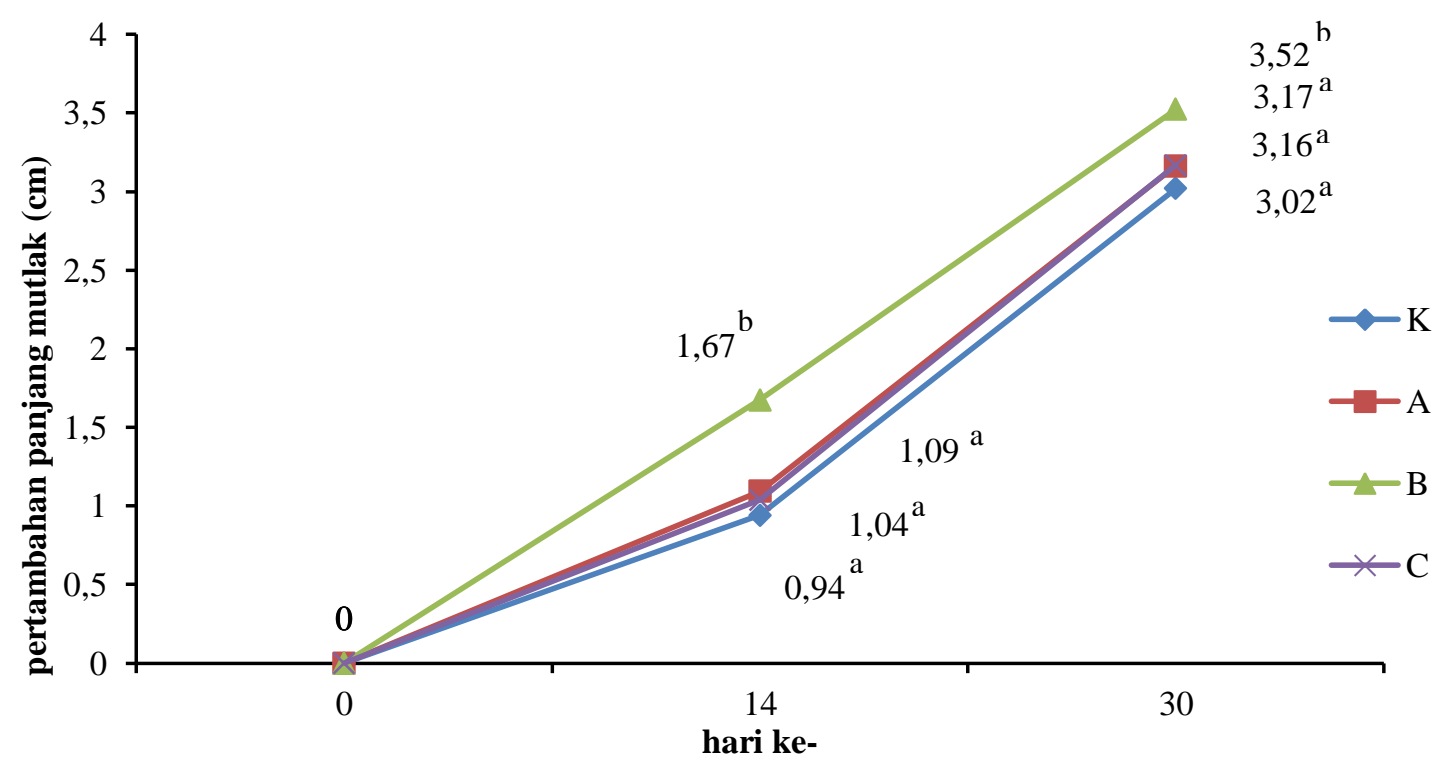

Gambar 2. Pertambahan panjang mutlak benih ikan nila pemeliharaan 0, 14 dan 30 hari. $\mathrm{K}=$ Kontrol, $\mathrm{A}=$ Tapioka, $\mathrm{B}=$ Molase, $\mathrm{C}=$ Terigu. Huruf yang berbeda di nilai grafik menunjukkan perbedaan nyata $(\mathrm{P}<0,05)$

Pengamatan tingkat kelangsungan hidup benih ikan nila menunjukkan bahwa perlakuan penambahan molase (B) menghasilkan kelangsungan hidup tertinggi dengan nilai $83.33 \%$, sedangkan nilai terendah pada kontrol (K) 67,78\% (Gambar 3). Hasil uji statistik menunjukkan bahwa persentase tingkat kelangsungan hidup benih ikan nila hari ke-14 tidak berbeda nyata $(\mathrm{P}>0,05)$, sedangkan pada akhir penelitian (30 hari) perlakuan pemberia molase (B) berbeda nyata dari kontrol (K) $(\mathrm{P}<0,05)$, dan tidak berbeda nyata dari perlakun pemberian tapiokan $(\mathrm{A})$ dan terigu (C) $(\mathrm{P}>0,05)$.

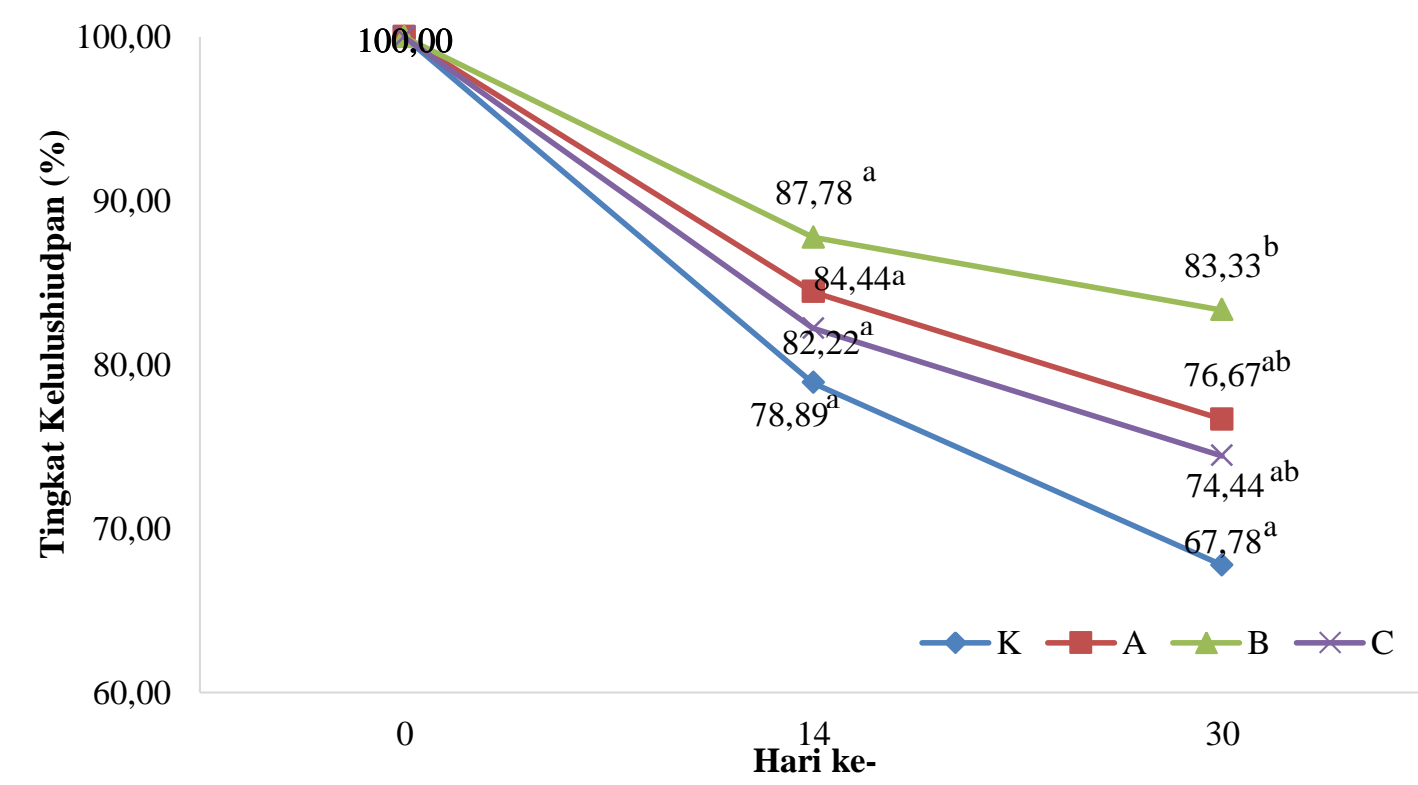

Gambar 3. Persentase kelulus hidupan benih ikan nila pemeliharaan 0, 14 dan 30 hari. $\mathrm{K}=\mathrm{Kontrol}$, $\mathrm{A}=$ Tapioka, $\mathrm{B}=$ Molase, $\mathrm{C}=$ Terigu. Huruf yang berbeda di nilai grafik menunjukkan perbedaan nyata $(\mathrm{P}<0,05)$ (uji Tukey) 
Pertambahan panjang mutlak pada hari ke-14 menunjukkan hasil yang tidak berbeda nyata antar perlakuan. Hal ini menunjukkan bahwa media pemeliharaan induk dan metode pemeliharaan larva belum memberikan pengaruh terhadap pertambahan panjang mutlak. Sedangkan pada pemeliharaan hari ke-30 pertambahan panjang mutlak benih ikan nila tertinggi pada perlakuan molase (B) sebesar 3,52 cm dan terendah pada perlakuan control $(\mathrm{K})$ yaitu $3.02 \mathrm{~cm}$. Perlakuan molase (B) berbeda nyata dari perlakuan lainya $(\mathrm{P}<0,05)$.

Pada perlakuan molase (B) terlihat bahwa diduga pertambahan yang berbeda nyata tersebut diakibatkan oleh kebutuhan nutrien yang dibutuhkan oleh benih tercukupi, sehingga kontribusi bioflok dalam pelakuan B ini signifikan. Hal ini didukung oleh laju perrtambahan panjang mutlak yang diperoleh dalam penelitian ini yang setara dengan hasil penelitian El Sayed (2002) dan El-Sayed dan Kawanna (2004). Hakim (2017) menyatakan bahwa nilai panjang mutlak ikan lele dipengaruhi oleh media pemeliharaan larva. Pemeliharaan benih dalam media bioflok dapat memberikan pengaruh yang signifikan hal ini diduga karena kandungan dalam flok terdiri atas protozoa, bakteria, 10 zooplankton dan mikroorganisme lain (Azim et al. 2008) dapat dimanfaatkan oleh benih untuk meningkatkan pertumbuhan salah satunya nilai panjang mutlak. Shafruddin et al. (2006) melaporkan bahwa pada benih ikan lele yang dipelihara dengan sistem budidaya dengan penambahan unsur $\mathrm{C}$ organik berupa tepung terigu memberikan perbedaan pada pertumbuhan panjang mutlak.

\section{Kualitas Air}

Kualitas air yang diukur pada penelitian ini meliputi oksigen terlarut, $\mathrm{pH}$, suhu dan Total Ammonia Nitrogen (TAN). Kualitas air hasil pengukuran selama penelitian pada wadah penelitian disajikan pada Tabel 1.

Tabel 1. Parameter kualitas air pada pemeliharaan benih ikan nila

\begin{tabular}{|c|c|c|c|c|c|}
\hline \multirow{2}{*}{ Parameter } & \multicolumn{3}{|c|}{ Perlakuan } & & \multirow{2}{*}{ Standar } \\
\hline & Kontrol (K) & Tapioka (A) & Molase (B) & Terigu $(\mathrm{C})$ & \\
\hline $\mathrm{DO}(\mathrm{mg} / \mathrm{L})$ & $5.00-6.90$ & $5.30-7.60$ & $5.30-7.50$ & $5.00-7.20$ & $\begin{array}{c}>3,0 \\
\text { (Avnimelech, 2007) }\end{array}$ \\
\hline $\mathrm{pH}$ & $5.00-6.90$ & $5.00-7.20$ & $5.00-6.90$ & $5.00-6.80$ & $\begin{array}{c}6,0-9,0 \\
\text { (Popma dan Masser 1999) }\end{array}$ \\
\hline Suhu $\left({ }^{\circ} \mathrm{C}\right)$ & $28.1-29.3$ & $28.2-29.9$ & $28.0-29.0$ & $28.4-30.0$ & $\begin{array}{c}25-32 \\
\text { (Hepher dan Pruginin 1981) }\end{array}$ \\
\hline TAN (mg/L) & $0,92-1,38$ & $0,48-0,74$ & $0,42-0,67$ & $0,52-0,87$ & $\begin{array}{c}<1 \\
(\text { SNI } 7550 \text { 2009) }\end{array}$ \\
\hline
\end{tabular}

Salah satu faktor yang mempegaruhi kelangsungan hidup adalah daya tahan terhadap perubahan lingkungan. Kelulushidupan yang diperoleh pada pemeliharaan hari ke-30 yaitu perlakuan $\mathrm{A}$ (tapioka) 76,67\%, B (molase) 83,33\%, C (terigu) $74,44 \%$ dan $\mathrm{K}$ (kontrol) $67,78 \%$. Hasil uji statistik menunjukan bahwa perlakuan $\mathrm{B}$ berbeda nyata dari perlakuan $\mathrm{K}(\mathrm{P}<0,05)$, akan tetapi tidak berbeda nyata dari perlakuan A dan C. Hasil ini menunjukan bahwa penambahan sumber karbon yang berbeda kedalam media budidaya berpengaruh terhadap kelulushidupan nila karena diduga keberadaan mikrobial flok yang dapat diterima oleh nila dengan baik perlakuan B namun hal sebaliknya terjadi pada perlakuan K sebab terdapat kematian ikan. Ekasari et al. (2015) melaporkan bahwa angka kelangsungan hidup larva ikan nila yang dipelihara pada media bioflok yang di uji stres salinitas dengan dosis $35 \mathrm{~g} / \mathrm{L}$ selama satu jam menunjukkani anggka 
kelangsungan lebih tinggi dibandingkan dengan larva ikan nila yang dipelihara dalam media kontrol. Diduga larva ikan nila yang dipelihara pada sistem bioflok memiliki ekspresi dari gen yang mengkode HSP70 yang merupakan heat shock protein yang melindungi sel dengan konformasinya yang mengikat dan melipat sedemikian rupa sehingga lebih stabil pada suhu tinggi. HSP70 memiliki kemampuan dalam sistem reparasi sel yang rusak akibat stres (Soeprijanto dan Assegaf, 2014).

Hasil berbeda didapat oleh Azim dan Little (2008) dan Rohmana et al. (2010) yang menunjukan tidak adanya pengaruh nyata penambahan karbohidrat terhadap kelulushidupan nila. Hal ini diduga kereana keberadaan mikrobial flok dalam media budidaya tidak mengakibatkan kerusakan pada jaringan insang, sirip, dan kulit. Pada perlakuan $\mathrm{B}$, namum memberikan kemaitan pada perlakuan $\mathrm{K}$. Umumnya, tingginya padatan tersuspensi dapat berakibat pada menurunnya kesehatan ikan, misalnya kerusakan jaringan insang. Namun, Azim dan Little (2008) tidak menemukan bukti potensi rusaknya jaringan insang akibat keberadaan bioflok. Penelitian ini membuktikan bahwa keberadaan mikrobial flok mempengaruhi kesehatan ikan.

Suhu rata-rata yang terukur selama penelitian adalah berkisar $28,1-30,0{ }^{0} \mathrm{C}$, hampir sama diperoleh oleh pada penelitian Hidayat et al. (2009) sebesar 28,36 ${ }^{\circ} \mathrm{C}$, sedangkan penelitian Ratannanda et al. (2011) suhu yang didapat $25,48{ }^{0} \mathrm{C}$. Menurut Hepher dan Pruginin (1981), kisaran suhu optimal untuk budidaya nila adalah $25-32{ }^{\circ} \mathrm{C}$.

Oksigen terlarut pada penelitai ini berkisar antara 5.00-7.60 mg/L, Oksigen terlarut optimum menurut Avnimelech (2007) adalah lebih besar dari $3 \mathrm{mg} / \mathrm{L}$. Hal ini berakibat pada maksimalnya pertumbuhan nila pada penelitian ini. $\mathrm{pH}$ pada penelitian ini masih dalam kisaran optimum untuk budidaya nila menurut (Popma dan Masser 1999) adalah 6,0-9,0.

Konsentrasi ammonia pada penelitian ini masih berada dalam batas yang diperbolehkan yaitu dibawah $1 \mathrm{mg} / \mathrm{L}$ (SNI, 2009). Stickney (2005) menambahkan kadar ammonia di media budidaya harus lebih rendah dari $0,8 \mathrm{mg} / \mathrm{L}$ untuk menghindari terjadinya efek toksik ammonia pada organisme akuatik. Konsentrasi TAN lebih tinggi pada perlakuan K (tanpa penambahan karbon) Penelitian Azim dan Little (2008) menghasilkan konsentrasi TAN lebih tinggi pada perlakuan tanpa bioflok. Budidaya dengan penerapan bioflok mengalami proses nitrifikasi yang juga besar selain immobilisasi ammonia kedalam bakteri.

\section{KESIMPULAN Kesimpulan}

Penambahan sumber karbon molase dapat meningkatkan panjang mutlak, pertumbuhan mutlak dan kelulus hidupan benih ikan nila yang dipelihara pada media budidaya berbasis bioflok

\section{DAFTAR PUSTAKA}

1. Aji, SB., A. Sudaryono, D. Herwanto. (2014). Pengaruh Penambahan Sumber Karbon Organik Berbeda terhadap Pertumbuhan dan Rasio Konversi Pakan Benih Lele (Clarias sp.) dalam Media Bioflok. Journal of Aquaculture Management and Technology, volume 3, pages 199-206

2. Asaduzzaman, M., MA. Wahab, MCJ. Verdegem, S. Huque, MA. Salam, ME. Azim. (2008). C/N Ratio Control and Substrate Addition for Periphyton Development Jointly Enhance Freshwater Prawn Macrobrachium rosenbergii Production in Ponds. Aquaculture, volume 280, pages 117-123. 
3. Avnimelech, Y. (1999). Carbon/Nitrogen Ratio as a Control Element In Aquaculture Systems. Aquaculture, volume 176, pages 227- 235.

4. . (2007). Feeding with Microbial Flocs by Tilapia in Minimal Discharge Bioflocs Technology Ponds. Aquaculture, volume 264, pages 140-147.

5. _ (2012). Biofloc Technology - a practical guide book, 2nd ed. The World Aquaculture Society. Baton Rouge. Louisiana. USA

6. Azim, ME. and DC. Little. (2008). The Biofloc Technology (BFT) In Indoor Tanks: Water Quality, Biofloc Composition, and Gowth and Welfare of Nile Tilapia (Oreochromis niloticus). Aquaculture, volume 283, pages 29-35.

7. Ballester, ELC., PC. Abreu, RO. Cavalli, M. Emerenciano, L. Abreu, W. Wasielesky. (2010). Effect of Practical Diet with Different Protein Levels on The Performance of Farfantepenaeus paulensis Juvenils Nursed in a Zero Exchange Suspended Microbial Floc Intensive System. Journal of Aquaculture nutrition, volume 16 pages 163-172.

8. Crab, R., T. Defoirdt, P. Bossier, W. Verstraete. (2012). Biofloc Technology in Aquaculture: Beneficial Effects and Future Challenges. Aquaculture. 356-357:351-356.

9. De Schryver, P., R. Crab, T. Detroit, N. Boon, W. Verstrate. (2008). The Basic of Bioflock Technology: The Added Value For Aquaculture. Aquaculture, volume 227, pages 125-137.

10. De Schryver P. and W. Verstraete. (2009). Nitrogen Removal from Aquaculture Pond Water by Heterotrophic Nitrogen Assimilation in Lab-Scale Sequarcing Batch Reactors. Biorecource Technology, volume 100, pages 1162-1167.

11. Ebeling, JM., MB. Timmons, JJ. Bisogni. (2006). Engineering Analysis of the Stoichiometry of Photoautotrophic, Autotrophic and Heterotrophic Removal of Ammonia-Nitrogen in Aquaculture Sistems. Aquaculture, volume 257, pages 346-358

12. Eduardo, LC., Ballester, O. Ronaldo, Cavalli, W. Wasielesky. (2011). Effect of Biofloc Technology (BFT) on the Early Postlarval Stage of Pink Shrimp Farfantepenaeus paulensis: Growth Performance, Floc Composition and Salinity Stress Tolerance. Aquaculture International volume 19, pages 891-901

13. Ekasari, J. (2009). Bioflocs Technology: Theory and Application in Intensive Aquaculture System. Jurnal Akuakultur Indonesia, volume 8(2), pages 117-126.

14. El-Sayed, AFM. (2002). Effects of Stocking Density and Feeding Levels on Growth and Feed Efficiency of Nile Tilapia (Oreochromis sp. L.) fry. Aquaculture Research, volume 33, pages 621-626.

15. El-Sayed, AFM, and M. Kawanna. (2004). Effects of Photoperiod on The Performance of Farmed Nile Tilapia (Oreochromis sp.): I. Growth, Feed Utilization Efficiency and Survival of Fry and Fingerlings. Aquaculture, volume 231, pages 393-402.

16. Emerenciano, M, G. Cuzon, J. Goguenheim, G. Gaxiola. (2011). Floc Contribution on Spawning Performance of Blue Shrimp Litopenaeus stylirostris. Aquaculture Research, volume 19, pages 891-901

17. Hakim, KA. (2017). Kinerja Pertumbuhan dan Kualitas Larva Ikan Lele yang Dipelihara dalam Media Bioflok dengan Penambahan Chlorella Sp. Skripsi. Departemen Budidaya Perairan. Fakultas Perikanan dan Ilmu Kelautan. Istitut Pertania Bogor. Bogor

18. Hargreaves, JA. 2006. Photosynthetic Suspended-Growth Sistems in Aquaculture. Aquacultural Engineering, volume 34, pages 344-363.

19. Hari, B., K. Madhusoodana, JT. Varghese, JW. Schrama, MCJ. Verdegem. (2004). Effects of Carbohydrate Addition on Production in Extensive Shrimp Culture Sistems. Aquaculture, volume 241, pages 179-194. 
20. Hepher, B. and Y. Pruginin. (1981). Commercial Fish Farming: with Special Reference to Fish Culture in Israel. John Wiley and Son. New York. 261 pp.

21. Hidayat, R., M. Fuadi, dan DS. Budi. (2009). Program Kreativitas Mahasiswa: Akuakultur Berbasis Trophic Level: Pemanfaatan Limbah Budidaya Ikan Lele Clarias Sp. oleh Ikan Nila Oreochromis niloticus Melalui Penambahan Molase. Institut Pertanian Bogor. Bogor. $11 \mathrm{hlm}$.

22. KKP. (2016). Kementerian Kelautan dan Perikanan dalam Angka. Kementerian Kelautan dan Perikanan. http://www.perikanan-budidaya. kkp.go.id. Jakarta (akses. 24 Agustus 2019)

23. Maharani, F. (2014). Bioflok Technology Application on the Cultivation of Nila Fish Seed (Oreochromis niloticus). Tesis. Program Pascasarjana. Universitas Terbuka Jakarta.

24. Manser, R. and H. Siegrist. (2006). Activated Sludge -Biofilm Flocs. Eawag News, 60e:28-30

25. Popma, T., and M. Masser. (1999). Tilapia Life History and Biology. Southern Regional Aquaculture Center Publication No. 283.

26. Purnomo, PD. (2012). Pengaruh Penambahan Karbohidrat pada Media Pemeliharaan terhadap Produksi Budidaya Intensif Nila (Oreochromis niloticus). Skripsi. Fakultas Perikanan dan Ilmu Kelautan, Universitas Diponegoro.

27. Ratannanda, R., I. Febriya, dan HA. Priatna. (2011). Program Kreativitas Mahasiswa: Akuakultur Berbasis Trophic Level: Budidaya Ikan Lele dan Ikan Nila dengan Sistem Bejana Berhubungan. Institut Pertanian Bogor. Bogor. $10 \mathrm{hlm}$.

28. Rivandi, DR. 2014. Pemeliharaan Induk dan Larva Ikan Nila Berbasis Teknologi Bioflok. Skripsi. Departemen Budidaya Perairan. Fakultas Perikanan dan Ilmu Kelautan. Istitut Pertanian Bogor. Bogor

29. Rohmana, D. (2009). Konversi Limbah Budidaya Ikan Lele, Clarias sp. menjadi Biomassa Bakteri Heterotrof untuk Perbaikan Kualitas Air dan Makanan Udang Galah, Macrobrachium Rosenbergii. Tesis. Sekolah Pasca Sarjana, Institut Pertanian Bogor. 64 hlm.

30. Rohmana, DS., B. Hanif, S. Rachman, Rosellia (2010). Aplikasi Teknologi Biofloc (BFT) pada Pendederan Intensif Ikan Nila dan Udang Galah. Makalah disampaikan pada Seminar Indoaqua pada Tanggal 4-6 Oktober 2010 di Bandar Lampung. Kementrian Kelautan dan Perikanan, Republik Indonesia.

31. Septiani, N, HW. Maharani, Supono. (2014). Pemanfaatan Bioflok dari Limbah Budidaya Lele Dumbo (Clarias gariepinus) sebagai Pakan Nila (Oreochromis niloticus). Jurnal Rekayasa dan Teknologi Budidaya Perairan. Volume 2(2), pages 267-272.

32. Soeprijanto, B., dan JH. Assegaf JH. (2014). Mekanisme peningkatan heat shock protein70 pada kanker payudara tikus yang diradiasi, pascapemberian ekstrak meniran (Phyllanthus niruri). Jurnal Veteriner, volume 15, pages 330 - 336.

33. Stickney, RR. (2005). Aquaculture: An introductory text. CABI Publishing. USA. 256p.

34. Sulistiani, R. (2015). Kualitas Larva Ikan Lele Clarias sp. yang Dipelihara dengan Teknologi Bioflok. Skripsi. Departemen Budidaya Perairan. Fakultas Perikanan dan Ilmu Kelautan. Istitut Pertanian Bogor. Bogor 